\title{
INFLUENCE OF HAFNIUM ON HIGH TEMPERATURE OXIDATION OF NiAl AND $\mathrm{Ni}_{3}$ Al ALLOYS
}

\begin{abstract}
The results presented in this paper concern the modification of $\mathrm{NiAl}$ and $\mathrm{Ni} \mathrm{i}_{3} \mathrm{Al}$ alloys with reactive elements that increase their high temperature oxidation resistance. Literature data indicate that even trace additions of Hf to aluminide coatings significantly improve the resistance to oxidation in the range of $1100-1150^{\circ} \mathrm{C}$, however the exact mechanism of its influence is not yet known. In order to determine the influence of various additions of Hf on high temperature oxidation of aluminide coatings, cyclic oxidation tests were performed at $1150^{\circ} \mathrm{C}$ of model $\mathrm{NiAl}$ and $\mathrm{Ni}_{3} \mathrm{Al}$ alloys with different $\mathrm{Hf}$ additions - from $0.25 \mathrm{wt} . \%$ to $1.5 \mathrm{wt} . \%$. High resolution electron microscopy, as well as chemical composition analysis techniques, were applied to perform a detailed characterisation of the influence of $H f$ on the substructure, chemical and phase composition in the nano scale of oxide scales formed during high temperature oxidation.
\end{abstract}

Keywords: high temperature oxidation, reactive elements, superalloys

\section{WPEYW HAFNU NA UTLENIANIE WYSOKOTEMPERATUROWE STOPÓW NiAl I Ni ${ }_{3} \mathrm{Al}$}

Wyniki przedstawione $w$ artykule dotycza modyfikacji tzw. pierwiastkami reaktywnymi faz wchodzacych $w$ sktad dyfuzyjnych powłok aluminidkowych stosowanych na łopatki turbin silników lotniczych w celu zwiększenia ich odporności na utlenianie wysokotemperaturowe. Dane literaturowe wskazuja, że nawet niewielki dodatek Hf w powłokach aluminidkowych bardzo silnie wptywa na wzrost odporności na utlenianie $w$ zakresie temperatury $1100 \div 1150^{\circ} \mathrm{C}$, jednak dokładny mechanizm jego wpływu nie jest do końca poznany. W celu określenia wpływu różnej zawartości Hf oraz scharakteryzowania mechanizmu jego oddziatywania na procesy utleniania wysokotemperaturowego powtok aluminidkowych przeprowadzono badania cyklicznego utleniania w temperaturze $1150^{\circ} \mathrm{C}$ stopów modelowych NiAl i $\mathrm{Ni}_{3} \mathrm{Al}$ o różnej zawartości $\mathrm{Hf}$ - od 0,05\% mas. do 1,5\% mas. Do przeprowadzenia szczegółowej analizy wpływu Hf na substrukture, skład chemiczny oraz fazowy w skali nano warstw tlenkowych powstajacych podczas utleniania wysokotemperaturowego wykorzystano techniki wysokorozdzielczej mikroskopii elektronowej oraz analizy składu chemicznego.

Stowa kluczowe: utlenianie wysokotemperaturowe, pierwiastki reaktywne, stopy żarowytrzymałe

\section{INTRODUCTION}

In 1937, Pfeil and Griffiths [1] patented a method for improving the oxidation resistance of alloys by doping them with the reactive elements (RE) that include i.a. $\mathrm{Hf}, \mathrm{Zr}$ and $\mathrm{Y}$. There are a number of research works proving the positive influence of reactive elements on high temperature oxidation processes [2-4], however the exact mechanism of their influence is still unclear. There is experimental evidence indicating that the presence of $\mathrm{Hf}, \mathrm{Y}$ and $\mathrm{Zr}$ has a particularly positive effect on the oxidation processes of alloys that form oxide scales composed of $\mathrm{Al}_{2} \mathrm{O}_{3}$ or $\mathrm{Cr}_{2} \mathrm{O}_{3}$, which leads to [4-8]: - an increase of oxide scale adherence to the substrate,

- hindering the growth of voids at the interface with the substrate and limiting sulphur segregation,

- altering the growth mechanism of the oxide scale,

- lowering the growth rate of the oxide scale - tenfold in the case of $\mathrm{Al}_{2} \mathrm{O}_{3}$ and 2-4 times in the case of $\mathrm{Cr}_{2} \mathrm{O}_{3}$,

- modification of the oxide scales structure.
The positive effect of reactive elements reveals itself during cyclic oxidation tests of alloys containing even trace amounts of REs - of the order of ppm. Pint et al. [9] performed cyclic oxidation tests of an uncoated René N5 and NiAl-Zr alloys at 1100 and $1200^{\circ} \mathrm{C}$. They showed that René N5 with 34 ppma Y exhibits a higher oxidation resistance than the alloy with no $\mathrm{Y}$ and $6 \mathrm{ppm}$ of sulphur, which is directly related to a higher adhesion of the $\mathrm{Al}_{2} \mathrm{O}_{3}$ oxide scale. Moreover, the resistance of the alloy with 34 ppma of $\mathrm{Y}$ is comparable to that of the alloy after desulfurisation performed in order to increase oxidation resistance [9].

In 1998, Pint proposed the dynamic segregation theory (DST) [6] which described the way reactive elements influence the growth of $\mathrm{Al}_{2} \mathrm{O}_{3}$ and $\mathrm{Cr}_{2} \mathrm{O}_{3}$ oxide scales. It states that the reactive elements present in superalloys as well as ODS alloys (oxide dispersion strengthened - e.g. FeCrAlY) in the form of fine dispersion particles firstly segregate to the metal-scale interface and then diffuse along the easiest paths i.e. grain boundaries in the direction of the oxidising atmosphere 
which is driven by the oxygen chemical potential gradient. It occurs once stable $\alpha-\mathrm{Al}_{2} \mathrm{O}_{3}$ and $\alpha-\mathrm{Cr}_{2} \mathrm{O}_{3}$ scales are formed because no impact of reactive elements on the growth rate of transient oxides has been observed so far, but only for the time of their presence which is prolonged. It is related to a higher solubility of reactive elements in i.a. $\theta-\mathrm{Al}_{2} \mathrm{O}_{3}$ [10]. Research works performed by Sheasby [11] and Nicolas-Chaubet [12] revealed that these elements are present in an ionic state, while Pint showed [6] that during oxidation, they are continuously diffusing (i.e. they are not static), which was indicated by the observation of nucleation and growth of particles containing $\mathrm{Hf}, \mathrm{Zr}$ and $\mathrm{Y}$ on grain boundaries of oxide scales [13, 14].

The dynamic segregation theory states that the reactive elements lower the parabolic rate constant $k_{p}$ by blocking the outward diffusion of $\mathrm{Al}^{3+}$ in $\alpha-\mathrm{Al}_{2} \mathrm{O}_{3}$. Pint suggested that this occurs because these elements diffuse slower along grain boundaries than $\mathrm{Al}$, thus retarding its diffusion [6]. In recent papers [5, 15], Heuer stated that the reactive elements hinder the outward diffusion of $\mathrm{Al}^{3+}$ cations by lowering the ionisation of $\mathrm{Al}$ at the metal-scale interface because of which it grows only due to the inward diffusion of $\mathrm{O}^{2-}$. As a result, the growth of the oxide scale occurs only at its interface with the substrate and not within it, which usually leads to compressive stresses. Therefore, $\alpha-\mathrm{Al}_{2} \mathrm{O}_{3}$ scales forming on $\mathrm{Zr}$ and $\mathrm{Hf}$ containing alloys are characterised by tensile stresses, which was shown by Veal et al. [16].

There are several methods to introduce reactive elements to high temperature coatings, such as ionic implantation [17, 18] or Chemical Vapour Deposition (CVD) [19], however these do not provide a sufficiently high concentration of these elements, and thus a continuous diffusion to the metal-scale interface as well as along its grain boundaries. Therefore, the most effective method is the addition of reactive elements to superalloys. It is a motivation for studies on oxidation processes of alloys with coatings in order to determine their influence on the behaviour of REs present in the substrate. These investigations are possible owing to the achievements in the scanning-transmission electron microscopy techniques STEM during the recent decades enabling the detection of $\mathrm{RE}$ segregation $[13,14,20-22]$.

\section{EXPERIMENTAL PROCEDURE}

The aim of the performed investigations was the characterisation of influence of various amounts of $\mathrm{Hf}$ (from $0.25 \mathrm{wt} . \%$ to $1.5 \mathrm{wt} . \%$ ) on the high temperature oxidation resistance of model $\mathrm{NiAl}$ and $\mathrm{Ni}_{3} \mathrm{Al}$ alloys. Cyclic oxidation tests were performed for these alloys at $1150^{\circ} \mathrm{C}$.

Cyclic oxidation tests are one of the basic criteria for assessing the properties of protective coatings and superalloys. Cyclic heating to a high temperature and cooling to room temperature causes the growth of oxides and then their spallation. Measurement of mass changes (gravimetric tests) is a commonly accepted criterion for assessing the durability of coatings. In the tests, a thermal cycle was used, consisting in heating the samples to $1150^{\circ} \mathrm{C}$, holding at the temperature for 23 hours, and then air cooling. Samples with a diam- eter of $14 \mathrm{~mm}$ and a thickness of $4 \mathrm{~mm}$ were weighed on an analytical balance with an accuracy of $10^{-5} \mathrm{~g}$ to determine the initial mass and then they were placed in ceramic boats. After each 23 hour oxidation cycle, the samples were weighed and the mass change was converted into a unit of area. The results were plotted on the graph of the change in weight and number of cycles. As a criterion of durability, the number of cycles at which the curve of mass changes crossed the socalled 'zero' line, below which there was a loss of mass of the samples below the initial mass, was used.

Surface structure investigation of the samples was performed using a FEI Inspect $\mathrm{F}$ scanning electron microscope. The microstructure and substructure in the cross-sections of the oxide scales formed during oxidation were analysed using a FEI TITAN 80-300 high resolution scanning transmission electron microscope (STEM) equipped with Energy Dispersive X-ray Spectrometer (EDS). The samples for STEM investigations were prepared using the focused ion beam (FIB) method.

\section{RESULTS}

Based on the performed cyclic oxidation test at $1150^{\circ} \mathrm{C}$, mass change graphs were plotted as a function of the number of 23 hour cycles (Fig. 1 and 2) illustrating the growth of oxide scales on the surface of the investigated samples. They contain the mass change for all of the investigated samples $-\mathrm{Ni}_{3} \mathrm{Al}$ and $\mathrm{Ni}_{3} \mathrm{Al}+$ $+0.25 \mathrm{Hf}, 0.5 \mathrm{Hf}, 1.5 \mathrm{Hf}$ (Fig. 1) and NiAl, NiAl + 0.25Hf, $0.5 \mathrm{Hf}, 1.5 \mathrm{Hf}$ (Fig. 2).

The analysis of mass changes of the samples subjected to the cyclic oxidation test showed that the highest durability (above 4523 -hour cycles at $1150^{\circ} \mathrm{C}$ ) was exhibited by the $\mathrm{NiAl}$ alloys modified with $0.25,0.5$ and $1.5 \mathrm{wt} . \% \mathrm{Hf}$ as well as the $\mathrm{Ni}_{3} \mathrm{Al}$ alloy with $1.5 \mathrm{wt} . \% \mathrm{Hf}$. In the case of all these samples no mass loss was observed below its initial value during the cyclic oxidation test. Moreover, in the case of all NiAl samples, a continuous mass gain was observed, while the mass of $\mathrm{Ni}_{3} \mathrm{Al}-1.5 \mathrm{Hf}$ was constant until the $34^{\text {th }}$ oxidation cycle, after which its gradual decrease occurred.

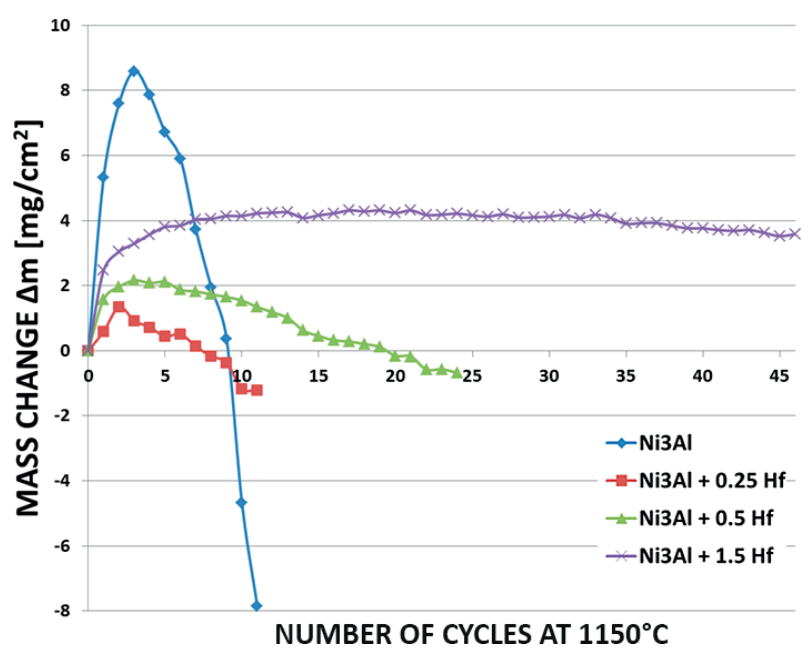

Fig. 1. Mass change diagram as a function of 23-hour cycles at $1150^{\circ} \mathrm{C}$ for $\mathrm{Ni}_{3} \mathrm{Al}$ and $\mathrm{Ni}_{3} \mathrm{Al}+0.25,0.5$ and $1.5 \mathrm{Hf}$

Rys. 1. Wykres zmiany masy w funkcji liczby 23-godzinnych cykli w temperaturze $1150^{\circ} \mathrm{C}$ dla próbek $\mathrm{Ni}_{3} \mathrm{Al}$ oraz $\mathrm{Ni}_{3} \mathrm{Al}+0,25,0,5$ i $1,5 \mathrm{Hf}$ 


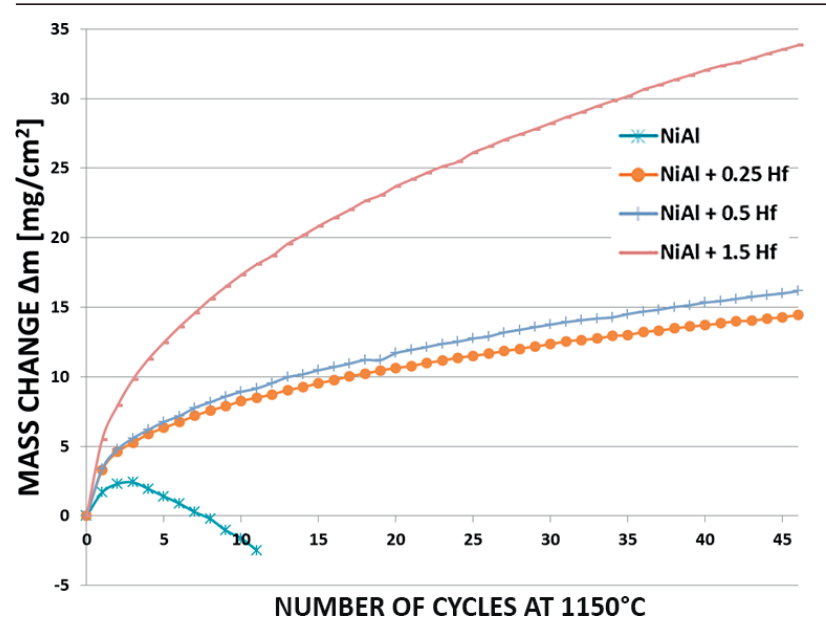

Fig. 2. Mass change diagram as a function of 23-hour cycles at $1150^{\circ} \mathrm{C}$ for $\mathrm{NiAl}$ and $\mathrm{NiAl}+0.25,0.5$ and $1.5 \mathrm{Hf}$

Rys. 2. Wykres zmiany masy w funkcji liczby 23-godzinnych cykli w temperaturze $1150^{\circ} \mathrm{C}$ dla próbek NiAl oraz $\mathrm{NiAl}+0,25,0,5$ i 1,5 Hf

The $\mathrm{Ni}_{3} \mathrm{Al}, \mathrm{NiAl}, \mathrm{Ni}_{3} \mathrm{Al}-0.25 \mathrm{Hf}$ and $\mathrm{Ni}_{3} \mathrm{Al}-0.5 \mathrm{Hf}$ alloys showed a mass loss below its initial value during the cyclic oxidation test. The highest durability among these alloys was shown by $\mathrm{Ni}_{3} \mathrm{Al}-0.5 \mathrm{Hf}$, the mass of which decreased below its initial value after 24 cycles.

In the case of an unmodified $\mathrm{Ni}_{3} \mathrm{Al}$ alloy, the highest mass gain was observed $-8.59 \mathrm{mg} / \mathrm{cm}^{2}$ after 4 oxidation cycles. The addition of $0.25 \mathrm{Hf}$ to $\mathrm{Ni}_{3} \mathrm{Al}$ led to over a six-fold decrease of the mass gain during high temperature oxidation to around $1.34 \mathrm{mg} / \mathrm{cm}^{2}$ (Fig. 3), which is the lowest measured value of mass gain among the investigated samples. The increase of $\mathrm{Hf}$ concentration - from 0.5 to 1.5 wt.\% leads to an increase in the mass gain of the $\mathrm{Ni}_{3} \mathrm{Al}$ alloy. In both cases it is, however, lower than in the unmodified alloy. The addition of $0.5 \mathrm{wt} . \%$ to $\mathrm{Ni}_{3} \mathrm{Al}$ causes an increase in durability to 24 cycles at $1150^{\circ} \mathrm{C}$, while the addition of $1.5 \mathrm{wt} . \%$ causes a rapid durability increase to over 46 cycles.

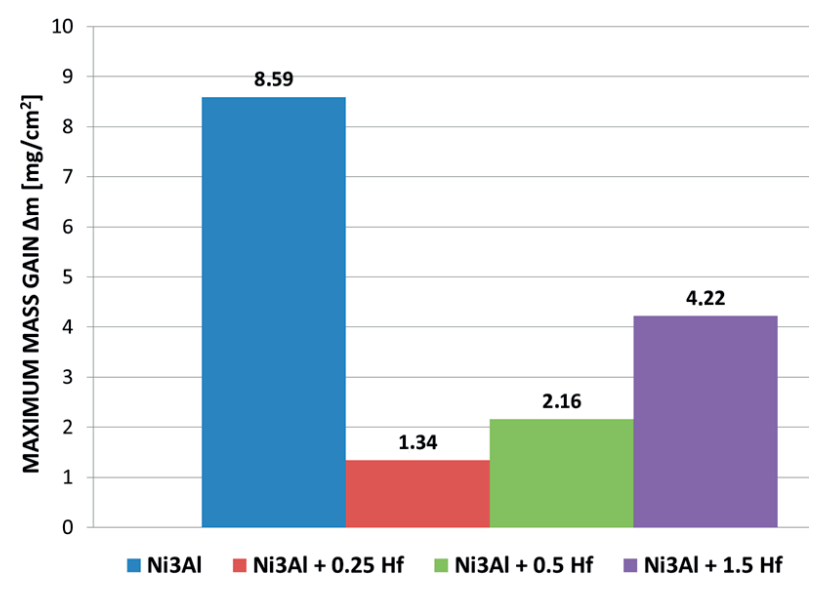

Fig. 3. Maximum mass gain during cyclic oxidation test at $1150^{\circ} \mathrm{C}$ for $\mathrm{Ni}_{3} \mathrm{Al}$ and $\mathrm{Ni}_{3} \mathrm{Al}+0.25,0.5$ and $1.5 \mathrm{Hf}$

Rys. 3. Maksymalny przyrost masy podczas testu cyklicznego utleniania $w$ temperaturze $1150^{\circ} \mathrm{C}$ dla próbek $\mathrm{Ni}_{3} \mathrm{Al}$ oraz $\mathrm{Ni}_{3} \mathrm{Al}+0,25,0,5$ i $1,5 \mathrm{Hf}$

The mass changes of NiAl alloys modified with $\mathrm{Hf}$ are presented in Fig. 4. Based on the performed analysis, it was concluded that with the increase in Hf content an increase of NiAl durability occurs, as well as

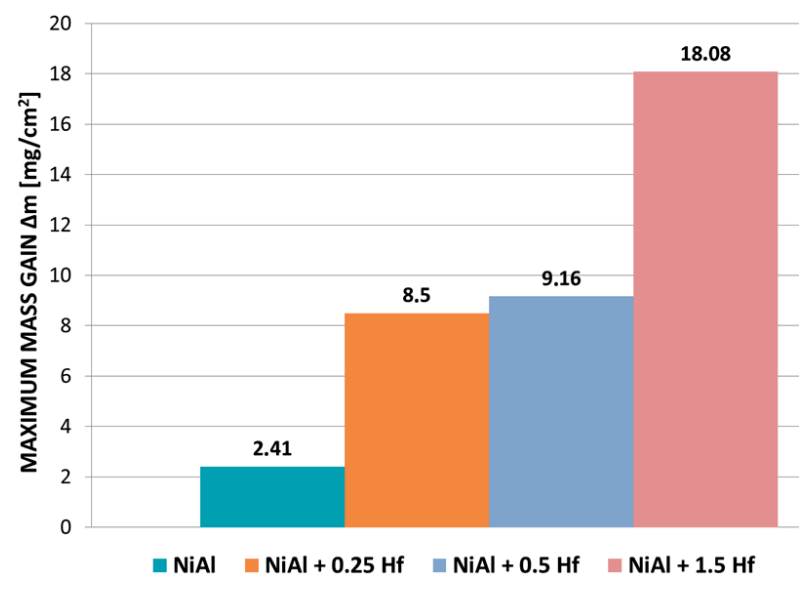

Fig. 4. Maximum mass gain during cyclic oxidation test at $1150^{\circ} \mathrm{C}$ for $\mathrm{NiAl}$ and $\mathrm{NiAl}+0.25,0.5$ and $1.5 \mathrm{Hf}$

Rys. 4. Wykres przedstawiający maksymalny przyrost masy podczas testu cyklicznego utleniania $w$ temperaturze $1150^{\circ} \mathrm{C}$ dla próbek $\mathrm{NiAl}$ oraz $\mathrm{NiAl}+0.25,0.5$ i $1.5 \mathrm{Hf}$

an increase of the maximum mass grain during the cyclic oxidation test. Contrary to unmodified $\mathrm{Ni}_{3} \mathrm{Al}$, the unmodified $\mathrm{NiAl}$ showed the lowest mass gain, however its lifetime was around 24 cycles. The addition of 0.25 and 0.5 wt.\% Hf resulted in an increase of mass to around 8.5 and $9.16 \mathrm{mg} / \mathrm{cm}^{2}$ respectively. A significant mass gain was observed in the case of NiAl-1.5Hf - around $18.08 \mathrm{mg} / \mathrm{cm}^{2}$. For all Hf-modified NiAl alloys no mass loss was observed.

Fig. 5 presents the photographs of $\mathrm{NiAl}$ and $\mathrm{Ni}_{3} \mathrm{Al}$ alloys samples as well as their modifications with hafnium in the initial condition (Fig. 5a), during cyclic oxidation test (Fig. 5b-d) and after cyclic oxidation test (Fig. 5-7).

In the initial state, all the samples were characterised by a shiny and polished surface (Fig. 5a). During the cyclic oxidation test, the growth of oxide scales was taking place on the surface of the samples, which is illustrated by the change in their appearance. After 523 -hour cycles at $1150^{\circ} \mathrm{C}$, the samples of $\mathrm{NiAl}$ alloy and its modifications were characterised by a grey and dull colour, while the $\mathrm{Ni}_{3} \mathrm{Al}$ samples were covered with a mixture of blue and green oxides. With the increase of Hf content a decrease in the amount of blue-green regions was observed, which were replaced by greybrown oxides. Moreover, in the case of the unmodified $\mathrm{Ni}_{3} \mathrm{Al}$ alloy, the oxide scale was characterised by a very low adherence to the substrate and its spallation occurred, which is visible in Fig. $5 c$ after 8 cycles of oxidation. Within the ceramic crucible in which the samples were placed, spalled oxidation products were observed for both $\mathrm{Ni}_{3} \mathrm{Al}$ and $\mathrm{Ni}_{3} \mathrm{Al}-0.25 \mathrm{Hf}$ samples. After 23 cycles at $1150^{\circ} \mathrm{C}, \mathrm{NiAl}, \mathrm{Ni}_{3} \mathrm{Al}$ and $\mathrm{Ni}_{3} \mathrm{Al}-0.25 \mathrm{Hf}$ were not subjected to further cyclic oxidation testing. The highest amount of green and blue oxides that spalled from the surface was observed in the place where the $\mathrm{Ni}_{3} \mathrm{Al}$ sample was present. Around the $\mathrm{NiAl}$ sample grey and brown oxides were found, while in the vicinity of the $\mathrm{Ni}_{3} \mathrm{Al}-0.25 \mathrm{Hf}$ sample the spalled oxides were blue and green. The modified $\mathrm{NiAl}$ as well as the $\mathrm{Ni}_{3} \mathrm{Al}-0.5$ and $\mathrm{Ni}_{3} \mathrm{Al}-1.5 \mathrm{Hf}$ samples were characterised by an adherent oxide scale.

The photographs of the $\mathrm{NiAl}$ and $\mathrm{Ni}_{3} \mathrm{Al}$ samples are presented in Fig. 6 and 7 respectively, and they illustrate the condition of their surface after the cy- 
a)
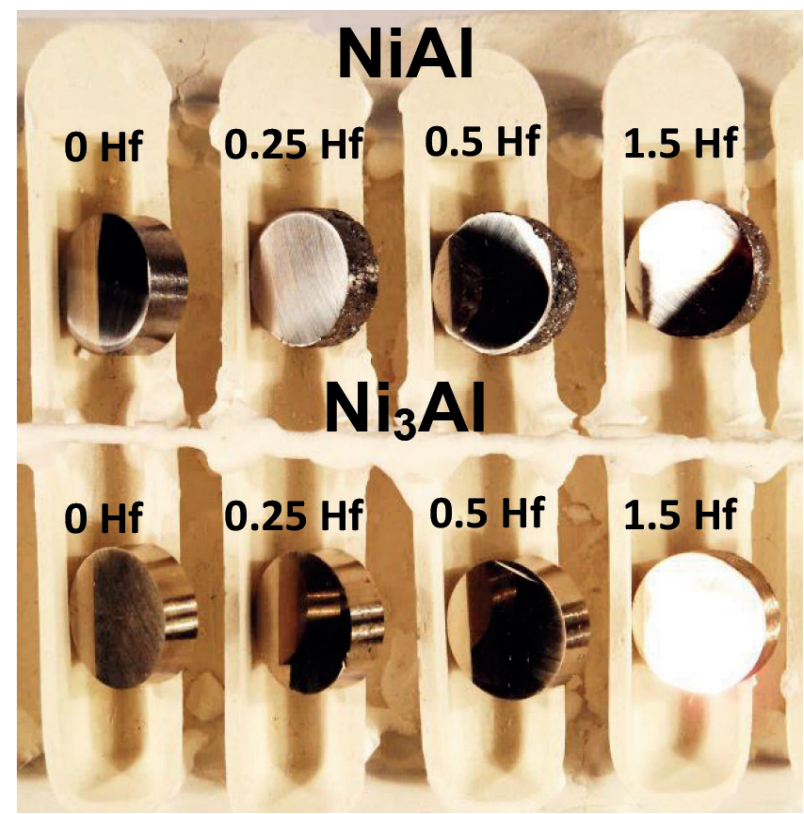

c)

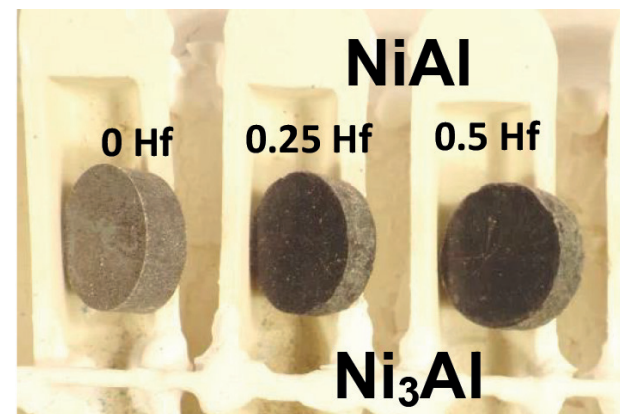

8 CYCLES AT $1150^{\circ} \mathrm{C}$

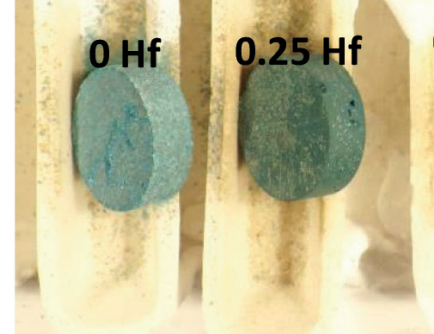

b)

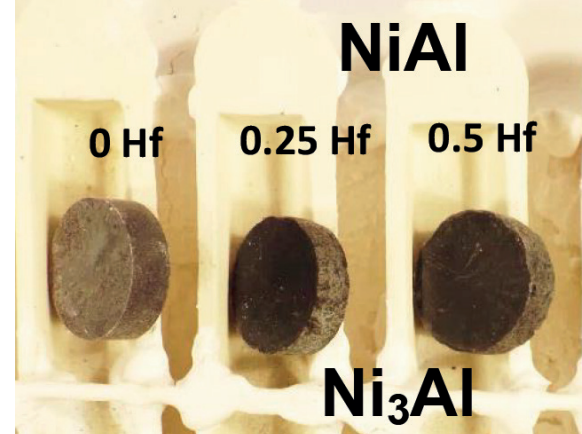

5 CYCLES AT $1150^{\circ} \mathrm{C}$

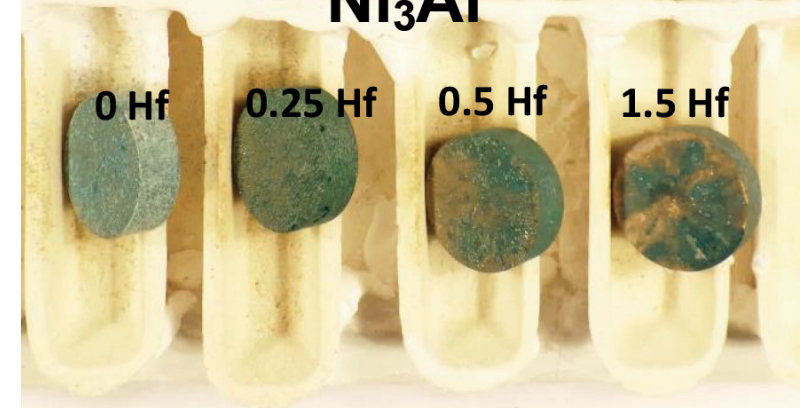

d)
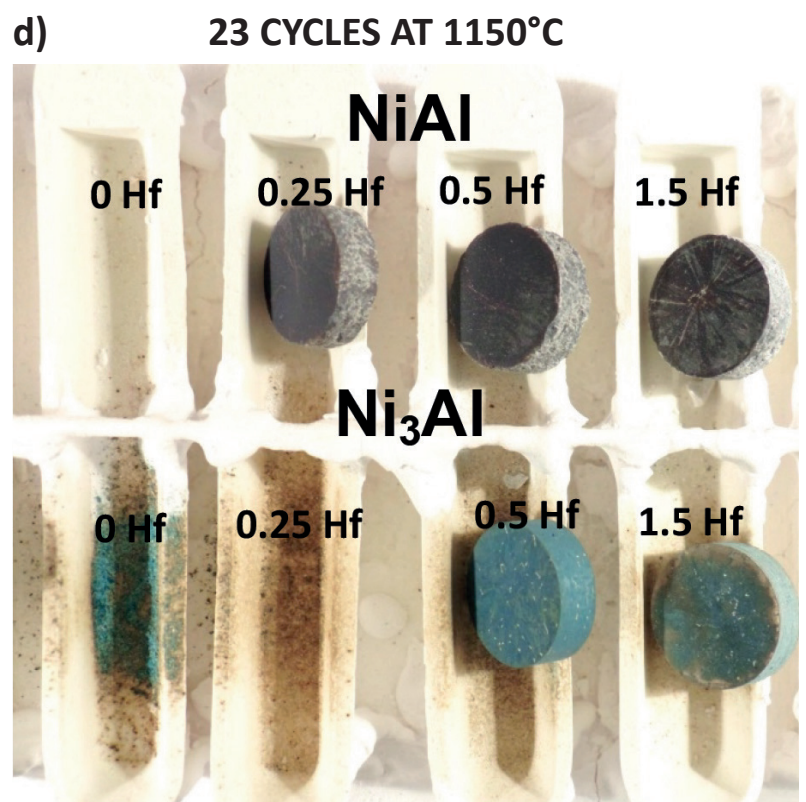

Fig. 5. Visual appearance of samples subjected to cyclic oxidation test: a) initial state and after, b) 5 cycles, c) 8 cycles and d) 23 cycles at $1150^{\circ} \mathrm{C}$

Rys. 5. Zdjęcia próbek poddanych testowi cyklicznego utleniania: a) stan wyjściowy, b) stan po 5 cyklach, c) stan po 8 cyklach i d) stan po 23 cyklach w temperaturze $1150^{\circ} \mathrm{C}$

clic oxidation test. In the case of the $\mathrm{NiAl}$ and $\mathrm{Ni}_{3} \mathrm{Al}$, $\mathrm{Ni}_{3} \mathrm{Al}-0.25 \mathrm{Hf}, \mathrm{Ni}_{3} \mathrm{Al}-0.5 \mathrm{Hf}$ samples, the photographs are presented after the samples crossed their initial mass during the cyclic oxidation test. The remaining samples for which no mass loss was observed were photographed after 46 23-hour cycles.

The surface of the samples that exhibited the lowest durability during the cyclic oxidation test, i.e. NiAl and $\mathrm{Ni}_{3} \mathrm{Al}$, was characterised by the presence of bright regions of metallic appearance which were the substrate exposed by the spallation of the oxide scale. It proves the low adherence of the oxide scale formed on these alloys. The remaining surface of the $\mathrm{NiAl}$ sample is covered by a grey-brown oxide scale, while the $\mathrm{Ni}_{3} \mathrm{Al}$ is characterised by a green-blue shade. The samples of $\mathrm{Ni}_{3} \mathrm{Al}$ modified with 0.25 wt.\% and 0.5 wt.\% Hf were also covered by green and blue oxides. Among the samples of $\mathrm{Ni}_{3} \mathrm{Al}$ alloy, the lowest amount of green and blue oxides was present on the sample modified with $1.5 \mathrm{wt} \% \mathrm{Hf}$. With the increase of Hf concentration in the alloy, the area of oxide spallation decreased, as well as the amount of green-blue oxides.

All the samples made of the NiAl alloy modified with Hf $-0.25,0.5$ and 1.5 wt.\% were covered by a compact and adherent oxide scale. Few sites with exposed substrate alloy were found on their surfaces, which proves the excellent oxide scale adherence in the presence of hafnium. It was also proven on the mass change diagrams during the cyclic oxidation test (Fig. 2).

The surface microstructure analyses were performed on the samples made of $\mathrm{NiAl}$ and $\mathrm{Ni}_{3} \mathrm{Al}$ alloys, as well as their modifications with various amounts of 


\section{NiAl \\ AFTER 11 CYCLES}
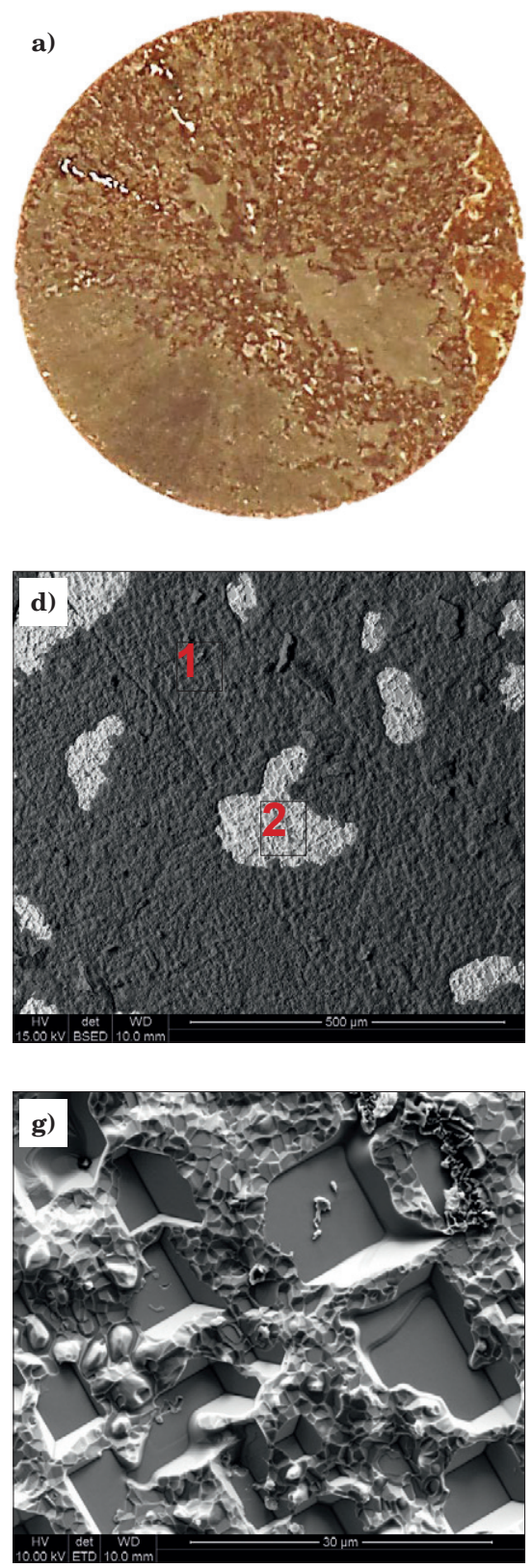

$\mathrm{NiAl}+0.25 \mathrm{Hf}$ AFTER 46 CYCLES
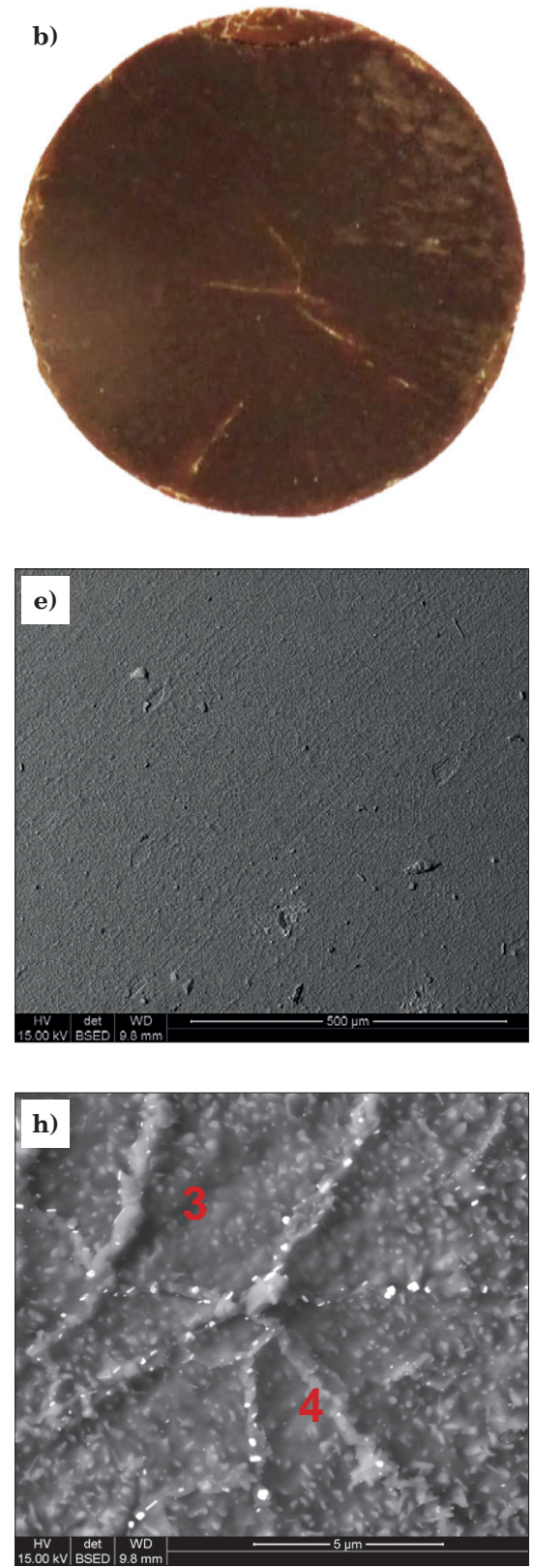

$\mathrm{NiAl}+1.5 \mathrm{Hf}$ AFTER 46 CYCLES
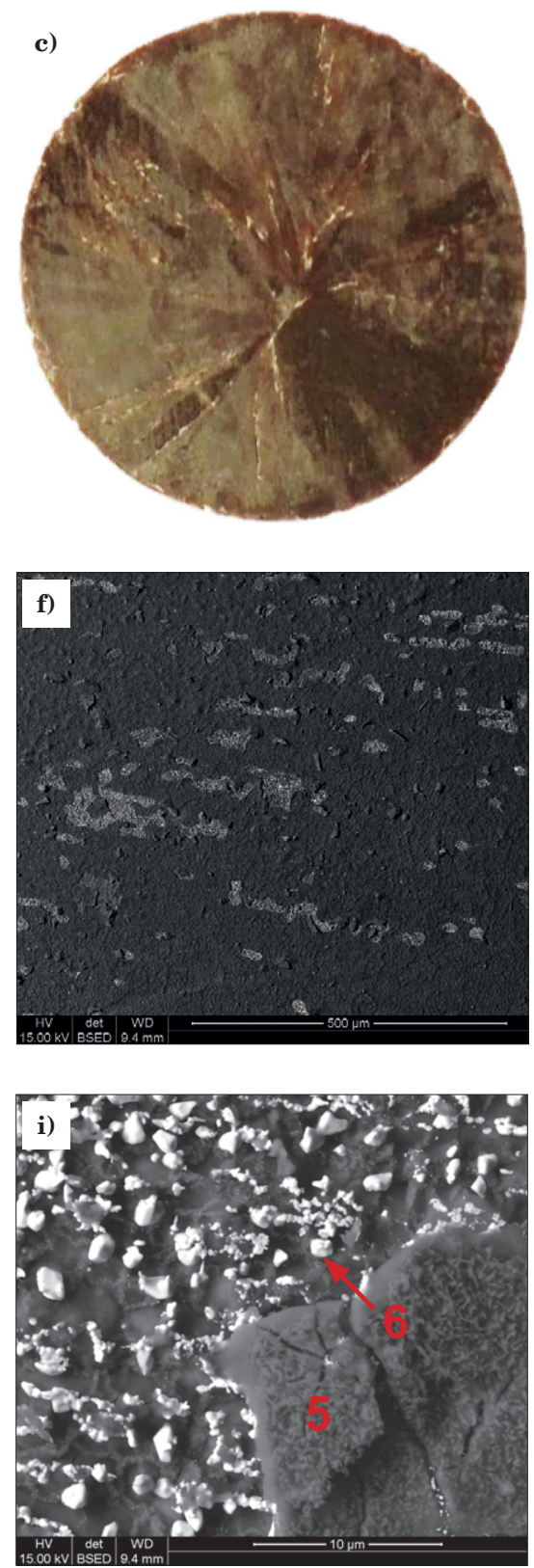

Fig. 6. Visual appearance and SEM-BSE images of the surface of the samples: NiAl after 11 cycles (a, d, g), NiAl-0.25Hf (b, e, h) and NiAl-1.5Hf $(c, f, i)$ after 4623 -hour cycles at $1150^{\circ} \mathrm{C}$

Rys. 6. Makrofotografie oraz obrazy SEM-BSE powierzchni próbek: NiAl po 11 cyklach (a, d, g) oraz NiAl-0,25Hf (b, e, h) i NiAl-1,5Hf (c, f, i) po 46 cyklach 23-godzinnych w $1150^{\circ} \mathrm{C}$

Table 1. Results of chemical composition analysis from microareas presented in Fig. 6

Tab. 1. Wyniki analizy składu chemicznego w mikroobszarach oznaczonych na rys. 6

\begin{tabular}{|c|c|c|c|c|c|c|}
\hline Point & $\mathbf{1}$ & $\mathbf{2}$ & $\mathbf{3}$ & $\mathbf{4}$ & $\mathbf{5}$ & $\mathbf{6}$ \\
\hline Element & at. \% & at. \% & at. \% & at. \% & at. \% & at. \% \\
\hline $\mathrm{Ni}$ & & 52.2 & & & & \\
\hline $\mathrm{Al}$ & 40 & 47.8 & 40 & 38.4 & 40 & 30.3 \\
\hline $\mathrm{O}$ & 60 & & 60 & 60.3 & 60 & 61.6 \\
\hline $\mathrm{Hf}$ & & & & 1.3 & & 8.1 \\
\hline
\end{tabular}




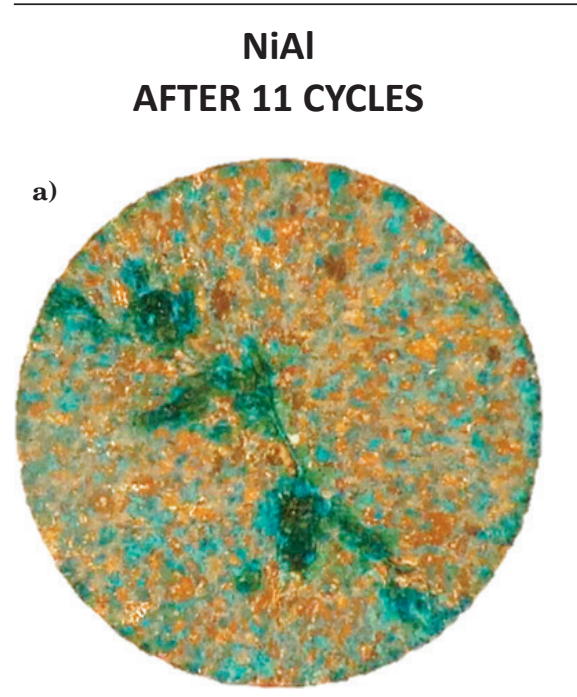

\section{$\mathrm{NiAl}+0.25 \mathrm{Hf}$ AFTER 46 CYCLES}
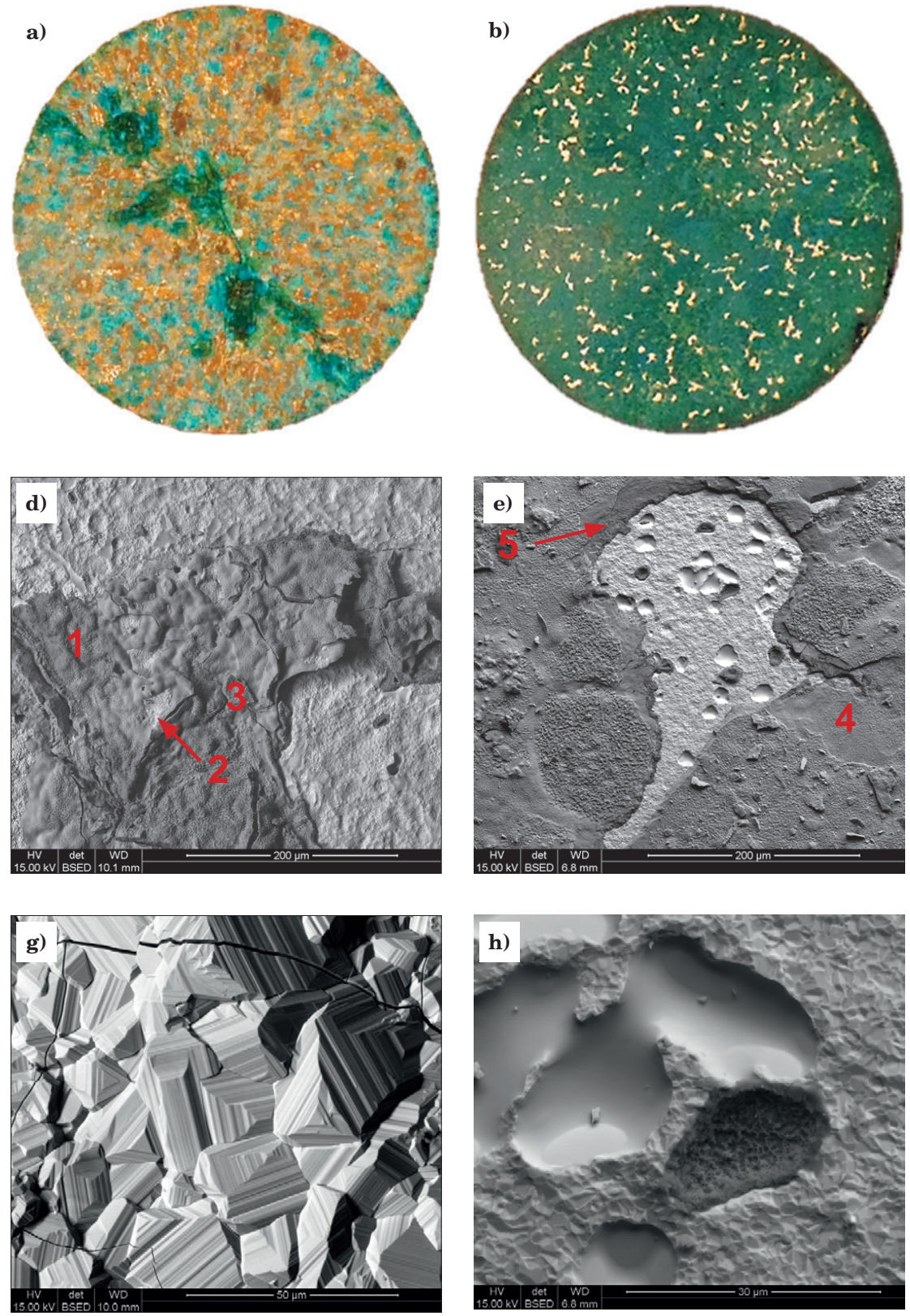

\section{$\mathrm{NiAl}+1.5 \mathrm{Hf}$ AFTER 46 CYCLES}
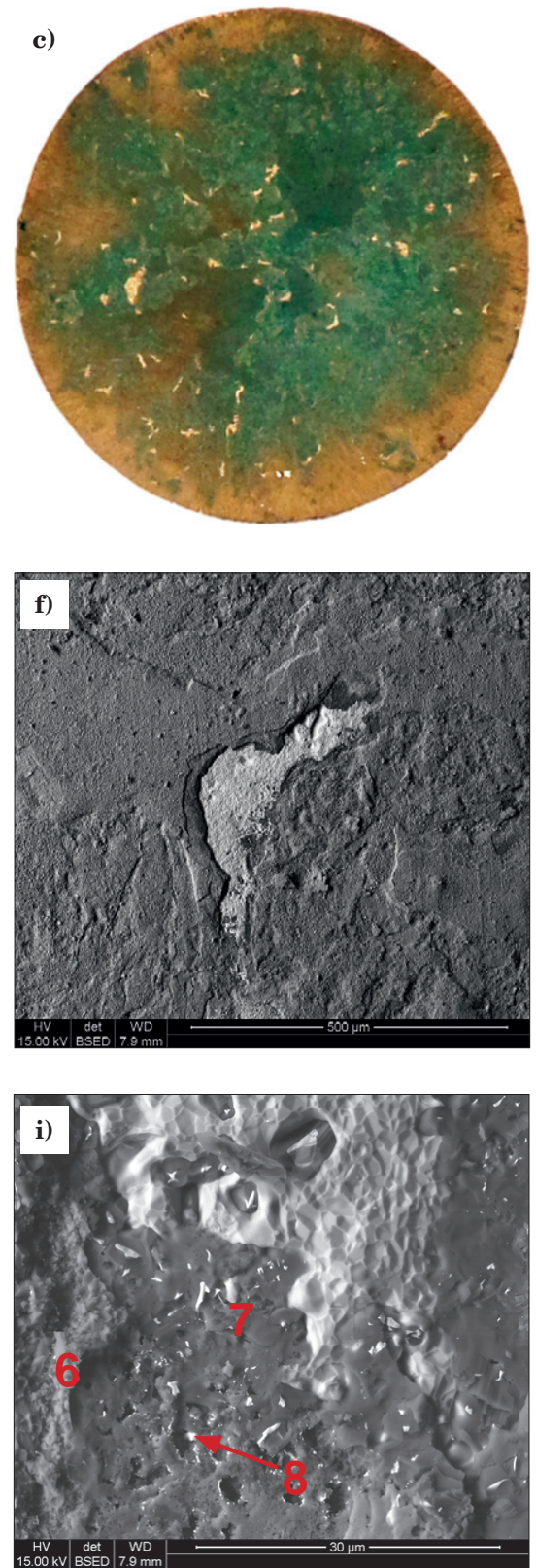

Fig. 7. Visual appearance and SEM-BSE images of the surface of samlpes: $\mathrm{Ni}_{3} \mathrm{Al}$ after $11 \mathrm{cycles}(\mathrm{a}, \mathrm{d}, \mathrm{g}), \mathrm{Ni} \mathrm{Al}_{3} \mathrm{Al}-25 \mathrm{Hf}$ after 12 cycles $(b, e, h)$ and $\mathrm{Ni}_{3} \mathrm{Al}-1.5 \mathrm{Hf}(\mathrm{c}, \mathrm{f}, \mathrm{i})$ after 46 23-hour cycles at $1150^{\circ} \mathrm{C}$

Rys. 7. Makrofotografie oraz obrazy SEM-BSE powierzchni próbek: $\mathrm{Ni}_{3} \mathrm{Al}$ po 11 cyklach (a, d, g) oraz Ni $\mathrm{Al}-0.25 \mathrm{Hf}$ po 12 cyklach $(b, e, h)$ i $\mathrm{Ni}_{3} \mathrm{Al}-1.5 \mathrm{Hf}(\mathrm{c}, \mathrm{f}, \mathrm{i})$ po 46 cyklach 23 -godzinnych w $1150^{\circ} \mathrm{C}$

Table 2. Results of chemical composition analysis from the microareas marked in Fig. 7 Tab. 2. Wyniki analizy składu chemicznego w mikroobszarach oznaczonych na rys. 7

\begin{tabular}{|c|c|c|c|c|c|c|c|c|}
\hline Element & $\begin{array}{c}1 \\
\text { at. } \%\end{array}$ & $\begin{array}{c}2 \\
\text { at. } \%\end{array}$ & $\begin{array}{c}3 \\
\text { at. } \%\end{array}$ & $\begin{array}{c}4 \\
\text { at. \% }\end{array}$ & $\begin{array}{c}5 \\
\text { at. } \%\end{array}$ & $\begin{array}{c}6 \\
\text { at. } \%\end{array}$ & $\begin{array}{c}7 \\
\text { at. } \%\end{array}$ & $\begin{array}{c}8 \\
\text { at. \% }\end{array}$ \\
\hline $\mathrm{Ni}$ & 1.7 & 50 & 3.9 & 5.7 & 0.6 & 3.8 & & 4.3 \\
\hline $\mathrm{Al}$ & 38.7 & & 36.9 & 35.4 & 39.5 & 37 & 40 & 27.7 \\
\hline $\mathrm{O}$ & 59.6 & 50 & 59.2 & 58.9 & 59.9 & 59.2 & 60 & 60.6 \\
\hline $\mathrm{Hf}$ & & & & & & & & 7.4 \\
\hline
\end{tabular}


Hf (0.25-1.5 wt.\%). The results of the investigation of $\mathrm{NiAl}$ alloys are presented in Fig. 6 and Table 1, while those for $\mathrm{Ni}_{3} \mathrm{Al}$ alloys are shown in Fig. 7 and Table 2 .

The SEM-BSE investigation enabled the differentiation of the areas with regard to the average atomic number of elements on the surfaces of the samples after the cyclic oxidation test. It was shown that the surface of $\mathrm{Ni}_{3} \mathrm{Al}$ alloys is covered by a complex oxide scale most probably consisting of $\mathrm{Al}_{2} \mathrm{O}_{3}$ oxide of grey shade and $\mathrm{NiO}$ or $\mathrm{Ni}_{2} \mathrm{Al}_{2} \mathrm{O}_{4}$ oxides characterised by a green-blue shade. The growth of nickel oxides is caused by a low $\mathrm{Al}$ concentration in the alloy and simultaneous oxidation of both $\mathrm{Ni}$ and $\mathrm{Al}$. The alternate spallation and growth of new oxides on the exposed substrate leads to a rapid mass loss of the samples, which is shown on the mass change diagrams from the cyclic oxidation test (Fig. 1). In the case of the unmodified $\mathrm{Ni}_{3} \mathrm{Al}$, the highest mass gain was observed $\left(8.59 \mathrm{mg} / \mathrm{cm}^{2}\right)$, which is related to the formation of nickel oxides of high growth rate and volume (Fig. 7d, g). These are characterised by a low adherence to the substrate which led to a rapid mass loss below its initial value. Based on the microstructural investigation of the surfaces of $\mathrm{Ni}_{3} \mathrm{Al}$ samples, it was observed that with the increase of hafnium concentration from 0 to $1.5 \mathrm{wt} . \%$ a decrease of the amount of nickel oxides occurs, which leads to the formation of a protective $\mathrm{Al}_{2} \mathrm{O}_{3}$ oxide scale. It is illustrated in the mass change diagrams (Fig. 7) as well as on the bar graph showing the maximum mass gain of the samples (Fig. 4). The addition of $0.25 \mathrm{wt} . \% \mathrm{Hf}$ to $\mathrm{NiAl}$ alloy leads to the inhibition of the formation of nickel oxides, thus it is characterised by the lowest mass gain among the investigated samples. Along with the increase of $\mathrm{Hf}$ concentration from 0.25 to $1.5 \mathrm{wt} . \%$ a gradual increase of mass gain was observed (Fig. 4), related most probably to the oxidation of hafnium. Moreover, an increase in the oxidation resistance was also observed, caused by increased adhesion of the $\mathrm{Al}_{2} \mathrm{O}_{3}$ oxide layer to the substrate in the presence of $\mathrm{Hf}$ (Fig. 1).

The surface investigation of $\mathrm{NiAl}$ alloys - unmodified and containing $0.25-1.5 \mathrm{wt} \% \mathrm{Hf}$ enabled the determination of hafnium influence on their oxidation processes. The surface of the unmodified alloy is characterised by the presence of a uniform $\mathrm{Al}_{2} \mathrm{O}_{3}$ oxide layer and numerous areas of exposed substrate where the spallation of the oxide scale occurred. It is confirmed by the analysis of the surface photographs after the cyclic oxidation test (Fig. 6). Due to the high $\mathrm{Al}$ concentration in the alloy, it does not form an oxide scale containing nickel oxides ( $\mathrm{NiO}$ or $\mathrm{Ni}_{2} \mathrm{Al}_{2} \mathrm{O}_{4}$ ) observed in the case of $\mathrm{Ni}_{3} \mathrm{Al}$. The analysis of the mass change curve during the cyclic oxidation test (Fig. 2) revealed that increasing the hafnium concentration leads to the increase of the alloy's oxidation resistance. In the case of the unmodified $\mathrm{NiAl}$ alloy after 8 oxidation cycles a mass loss was observed below its initial value, while the alloys containing 0.25 to 1.5 wt.\% Hf exhibited excellent oxidation resistance during the 46 cycles at $1150^{\circ} \mathrm{C}$. Since the oxide scale growing during the oxidation of $\mathrm{NiAl}$ alloy is composed of $\mathrm{Al}_{2} \mathrm{O}_{3}$ alone, the mass change is directly dependent on its adherence to the substrate. It appears that with the increase in the concentration of hafnium the adherence of oxide scale increases as well. Similarly to the $\mathrm{Ni}_{3} \mathrm{Al}$ alloy, in the case of $\mathrm{NiAl}$ along with the increase in the hafnium concentration the maximum mass gain during cyclic oxidation increases simultaneously, which is undoubtedly related to the formation of hafnium oxides (Fig. 4). They were observed on grain boundaries of the $\mathrm{Al}_{2} \mathrm{O}_{3}$ oxide scale formed on $\mathrm{Ni}_{3} \mathrm{Al}-0.25 \mathrm{Hf}$ in the form of precipitates of $300 \mathrm{~nm}$ (Fig. 6h). With increased Hf concentration in the NiAl alloy to $1.5 \mathrm{wt} . \%$, the hafnium oxides develop to around $1.5 \mu \mathrm{m}$ (Fig. 6i), which leads to an increase in sample mass gain. Moreover, the formation of hafnium oxides was observed within the oxide scale in the regions where it suffered from decohesion (Fig. 6i). This can indicate the negative influence of a too high Hf concentration on the durability of the oxide scale.

In order to determine the behaviour of hafnium as a modification of the investigated alloys, a detailed microstructural STEM analysis was performed of the oxide scales formed during high temperature oxidation at $1150^{\circ} \mathrm{C}$. Fig. $8-10$ present the results of STEM investigation of the oxide scale formed on the Hf-free $\mathrm{Ni}_{3} \mathrm{Al}$ alloy, while Fig. 11-13 present the results for the $\mathrm{Ni}_{3} \mathrm{Al}-0.25 \mathrm{Hf}$ alloy.

The oxide scale formed on the $\mathrm{Hf}$-free $\mathrm{Ni}_{3} \mathrm{Al}$ alloy is characterised by a double layered microstructure (Fig. 8a, b) which is composed of the outer zone containing $\mathrm{NiAl}_{2} \mathrm{O}_{4}$ (Fig. 8c, d and Fig. 10 d-f), which most probably formed due to the reaction between $\mathrm{NiO}$ and transient $\mathrm{Al}_{2} \mathrm{O}_{3}$ (e.g. $\theta-\mathrm{Al}_{2} \mathrm{O}_{3}$ ), as well as an internal zone containing equiaxed $\alpha-\mathrm{Al}_{2} \mathrm{O}_{3}$ grains (Fig. 10a-c). Between the outer and inner zone, there is a region with porous $\alpha-\mathrm{Al}_{2} \mathrm{O}_{3}$ that formed due to the transformation from $\theta-\mathrm{Al}_{2} \mathrm{O}_{3}$ and volumetric changes that accompany it (Fig. 8c, d). The STEM investigation of the $\alpha-\mathrm{Al}_{2} \mathrm{O}_{3}$ region in the inner zone of the oxide scale revealed the presence of nanometric $\mathrm{NiS}_{2}$ precipitates of around $30 \mathrm{~nm}$. Fig. 9. shows the distribution of elements in the area where the sulphides are present, while Fig. $8 \mathrm{f}$ shows the electron diffraction of $\mathrm{NiS}_{2}$. These are formed due the diffusion of sulphur to the surface of the oxidised alloy. It is proven by the STEM-HAADF images of the oxide layer shown in Fig. 8e, $\mathrm{f}$ where the $\mathrm{NiS}_{2}$ precipitates are present only in the inner zone of the oxide scale. During the growth of the oxide scale, due to inward oxygen diffusion, these are embedded in grain boundaries of the $\alpha-\mathrm{Al}_{2} \mathrm{O}_{3}$. Besides the nanometric $\mathrm{NiS}_{2}$ precipitates no other phases containing sulphur were found.

The microstructure of the oxide scale formed on the $\mathrm{Ni}_{3} \mathrm{Al}$ alloy with $0.25 \mathrm{wt} . \% \mathrm{Hf}$ is also composed of two zones (Fig. 11a, b) that include the external porous one with $\mathrm{NiAl}_{2} \mathrm{O}_{4}$ as well as an internal one with $\alpha-\mathrm{Al}_{2} \mathrm{O}_{3}$ grains visible in Fig. 11c, d. The phase constituents of the oxide scale were identified using electron diffraction, the results of which are shown in Fig. 13. Contrary to the Hf-free alloy, in the presence of $0.25 \mathrm{wt} \% \mathrm{Hf}$ the $\alpha-\mathrm{Al}_{2} \mathrm{O}_{3}$ grains are characterised by a good adherence to the substrate and a columnar structure, which is characteristic of Hf modified alloys. The elemental distribution analysis revealed the presence of $\mathrm{Hf}$ on the $\alpha-\mathrm{Al}_{2} \mathrm{O}_{3}$ grain boundaries (Fig. 12). Moreover, the presence of $\mathrm{Hf}$ was also found in the bright precipitates within the outer zone of the oxide scale. In contrast to the $\mathrm{Hf}$-free $\mathrm{Ni}_{3} \mathrm{Al}$ alloy, no sulphides were found in the $\mathrm{Ni}_{3} \mathrm{Al}-1.5 \mathrm{Hf}$ alloy. 

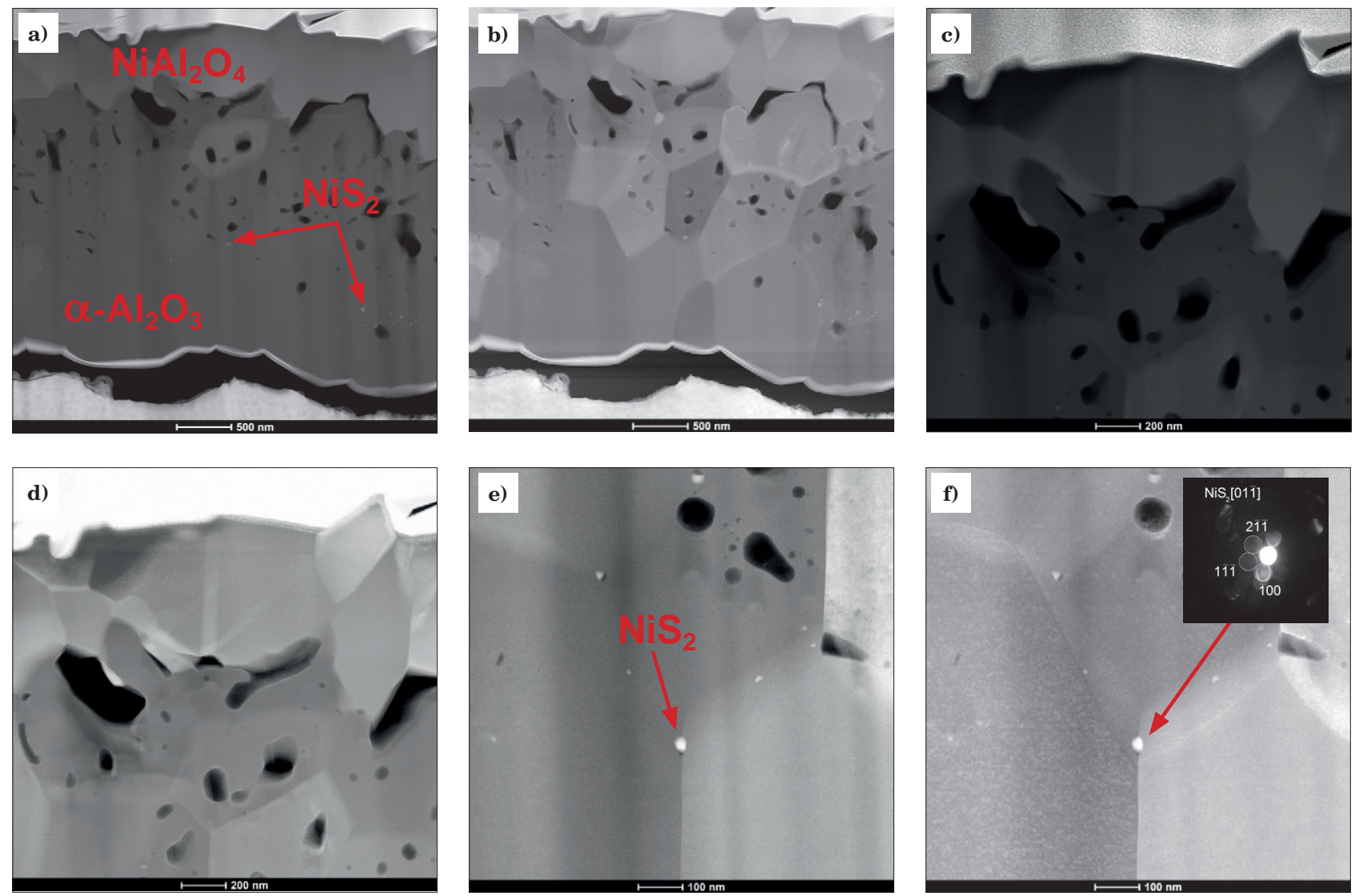

Fig. 8. STEM-HAADF and DF images of the oxide scale microstructure formed on the $\mathrm{Ni}_{3} \mathrm{Al}$ alloy during 11 cycles of oxidation at $1150^{\circ} \mathrm{C}(\mathrm{a}, \mathrm{b})$, interface between the internal $\alpha-\mathrm{Al}_{2} \mathrm{O}_{3}$ and external $\mathrm{NiAl}_{2} \mathrm{O}_{4}$ zones $(\mathrm{c}, \mathrm{d})$, grain boundary of $\alpha-\mathrm{Al}_{2} \mathrm{O}_{3}$ with a visible $\mathrm{NiS}_{2}$ sulphide (e, f)

Rys. 8. Obrazy STEM-HAADF i DF mikrostruktury warstwy tlenkowej powstałej na stopie $\mathrm{Ni}_{3} \mathrm{Al}$ podezas 11 cykli utleniania w temperaturze $1150^{\circ} \mathrm{C}(\mathrm{a}, \mathrm{b})$, granica rozdziału pomiędzy wewnętrzną strefą $\alpha-\mathrm{Al}_{2} \mathrm{O}_{3}$ ora zewnętrzną strefą $\mathrm{NiAl}_{2} \mathrm{O}_{4}(\mathrm{c}, \mathrm{d})$, granica ziarn $\alpha-\mathrm{Al}_{2} \mathrm{O}_{3}$ z widocznym siarczkiem niklu $\mathrm{NiS}_{2}(\mathrm{e}, \mathrm{f})$
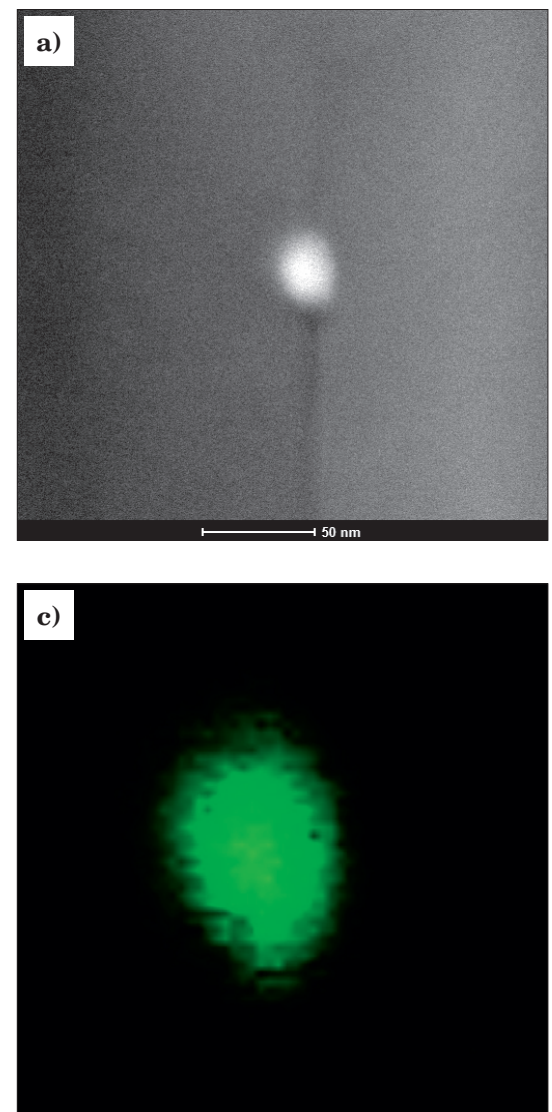
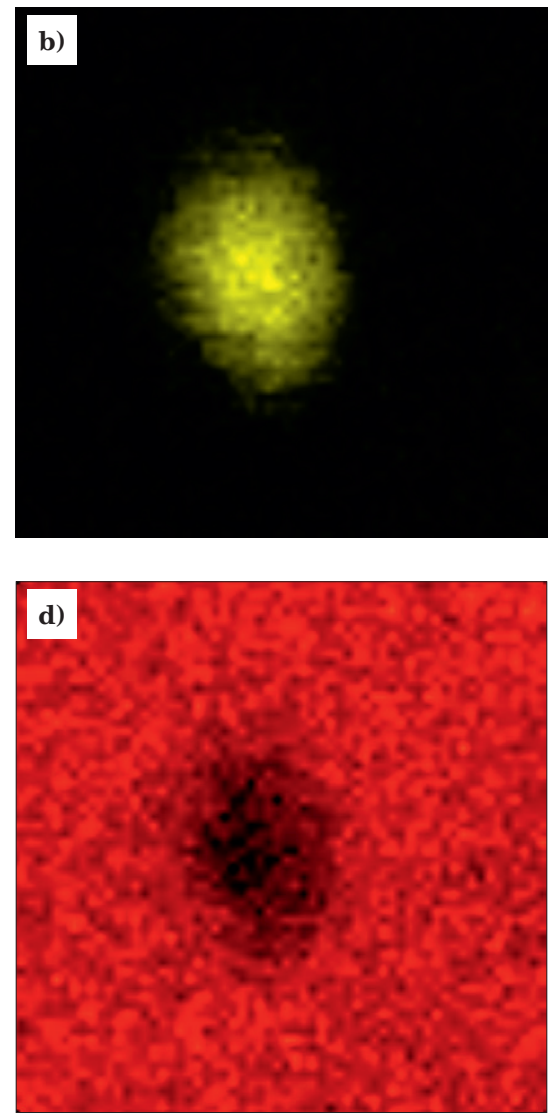

Fig. 9. Elemental distribution in the area of $\mathrm{NiS}_{2}$ on grain boundaries of $\alpha-\mathrm{Al}_{2} \mathrm{O}_{3}(\mathrm{a}), \mathbf{S}(\mathrm{b}), \mathrm{Ni}(\mathrm{c}), \mathrm{O}$ (d)

Rys. 9. Rozmieszezenie pierwiastków w obszarze występowania siarczku niklu $\mathrm{NiS}_{2}$ na granicy ziarn tlenku $\alpha-\mathrm{Al}_{2} \mathrm{O}_{3}$ (a), $\mathbf{S}(\mathrm{b}), \mathrm{Ni}$ (c), $\mathrm{O}$ (d) 

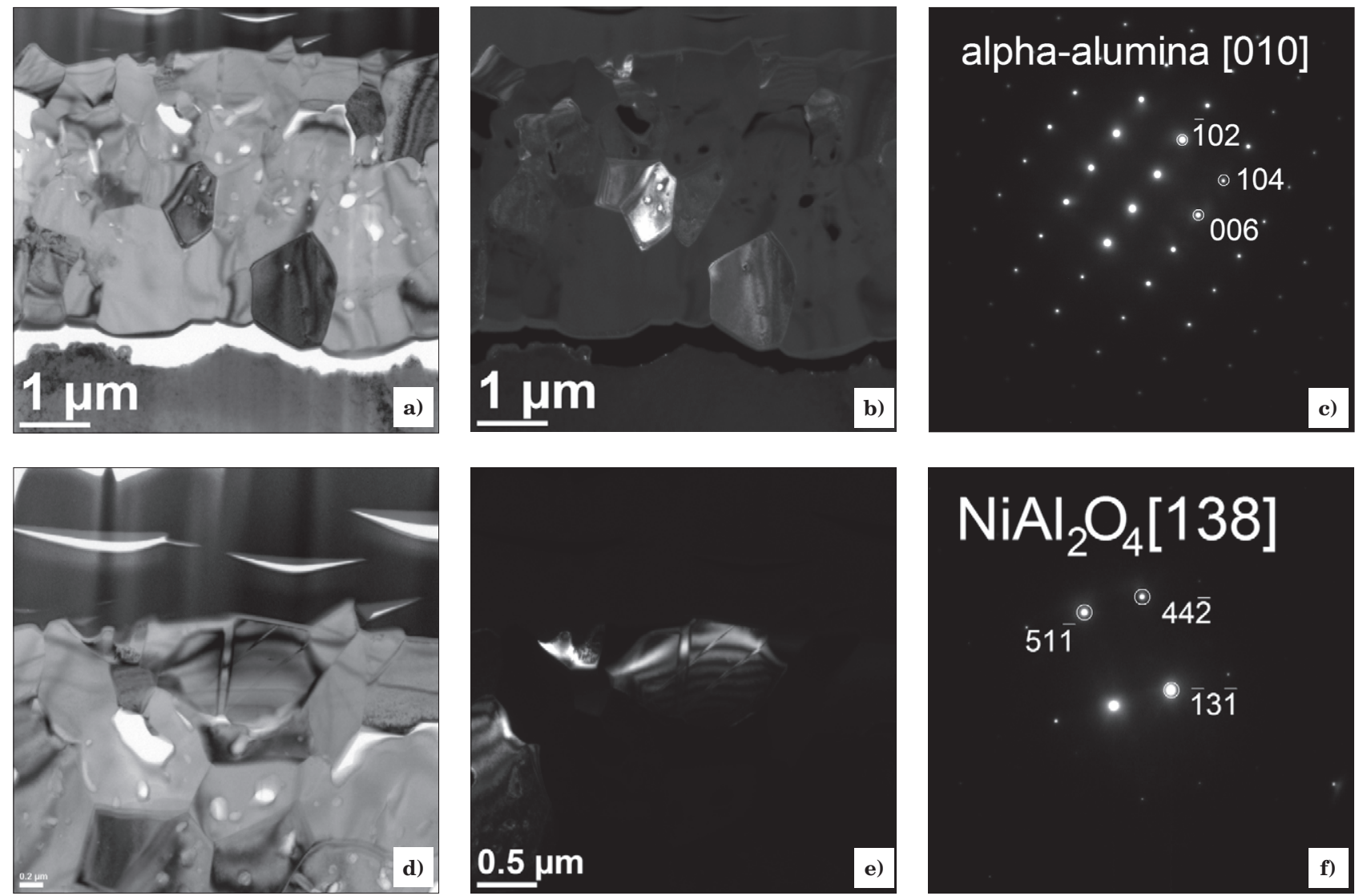

Fig. 10. Bright field TEM image of the oxide scale formed on $\mathrm{Ni}_{3} \mathrm{Al}$ alloy during 1123 -hour cycles at $1150^{\circ} \mathrm{C}(\mathrm{a})$, dark field $\mathrm{TEM}$ and electron diffraction for the $\alpha-\mathrm{Al}_{2} \mathrm{O}_{3}$ phase $(\mathrm{b}, \mathrm{c})$, bright field, dark field and electron diffraction of $\mathrm{NiAl}_{2} \mathrm{O}_{4}(\mathrm{~d}-\mathrm{f})$

Rys. 10. Obraz pola jasnego TEM warstwy tlenkowej powstałej na stopie $\mathrm{Ni}_{3} \mathrm{Al}$ podezas 11 23-godzinnych cykli utleniania w temperaturze $1150^{\circ} \mathrm{C}(\mathrm{a})$, obraz pola ciemnego TEM i dyfrakcja elektronowa dla fazy $\alpha-\mathrm{Al}_{2} \mathrm{O}_{3}(\mathrm{~b}$, c), obrazy pola jasnego i ciemnego oraz dyfrakcja elektronowa dla fazy $\mathrm{NiAl}_{2} \mathrm{O}_{4}$ (d-f)
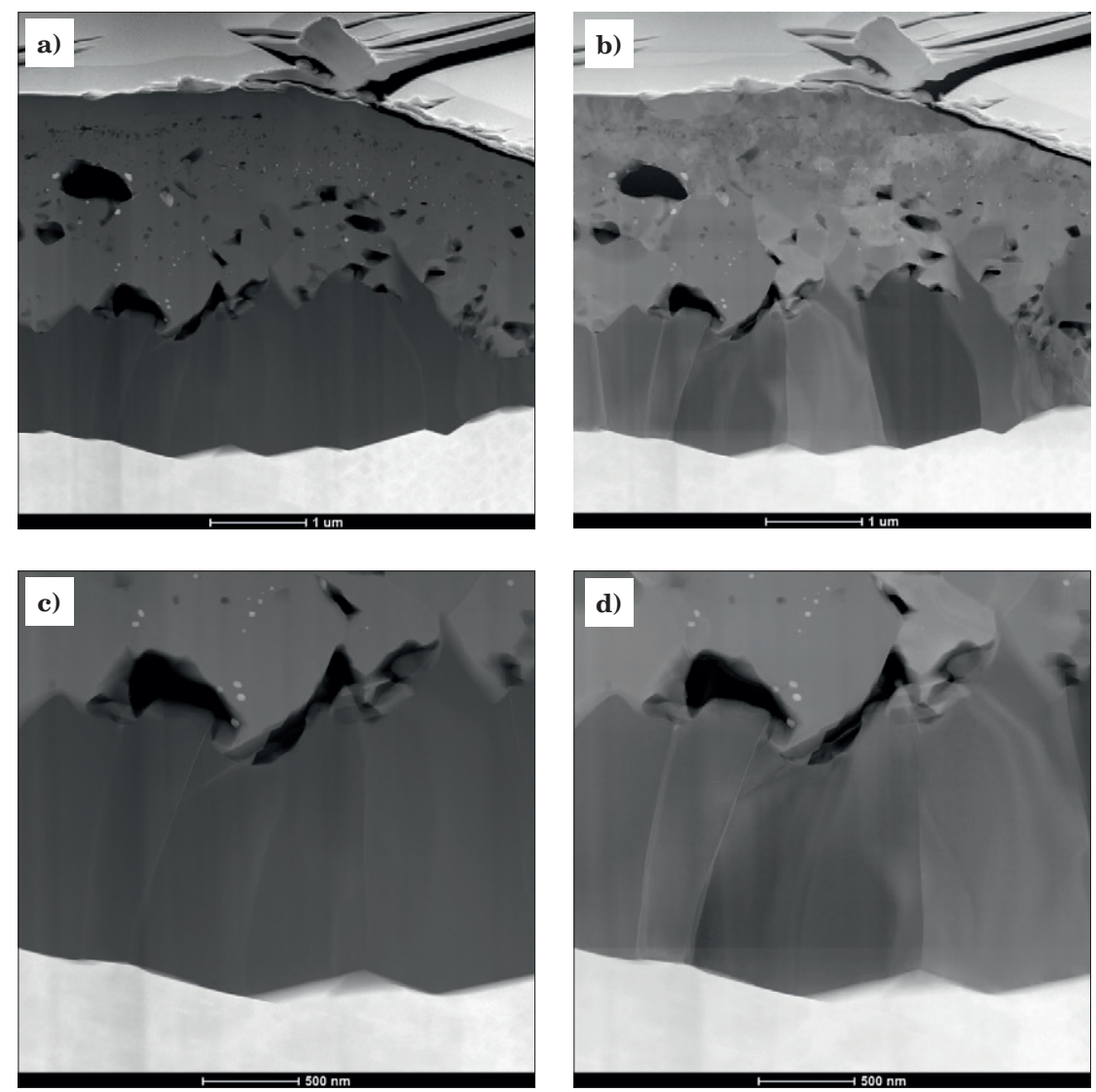

Fig. 11. STEM-HAADF and DF images of the oxide scale microstructure formed on $\mathrm{Ni}_{3} \mathrm{Al}$ during 12 23-hour cycles at $1150^{\circ} \mathrm{C}(\mathrm{a}, \mathrm{b})$, metal-scale interface $(\mathrm{c}, \mathrm{d})$ Rys. 11. Obrazy STEM-HAADF i DF mikrostruktury warstwy tlenkowej powstałej na stopie $\mathrm{Ni}_{3} \mathrm{Al}$ podczas 12 23-godzinnych cykli $w$ temperautrze $1150^{\circ} \mathrm{C}(\mathrm{a}, \mathrm{b})$, granica rozdziału warstwy tlenkowej z podłożem $(c, d)$ 

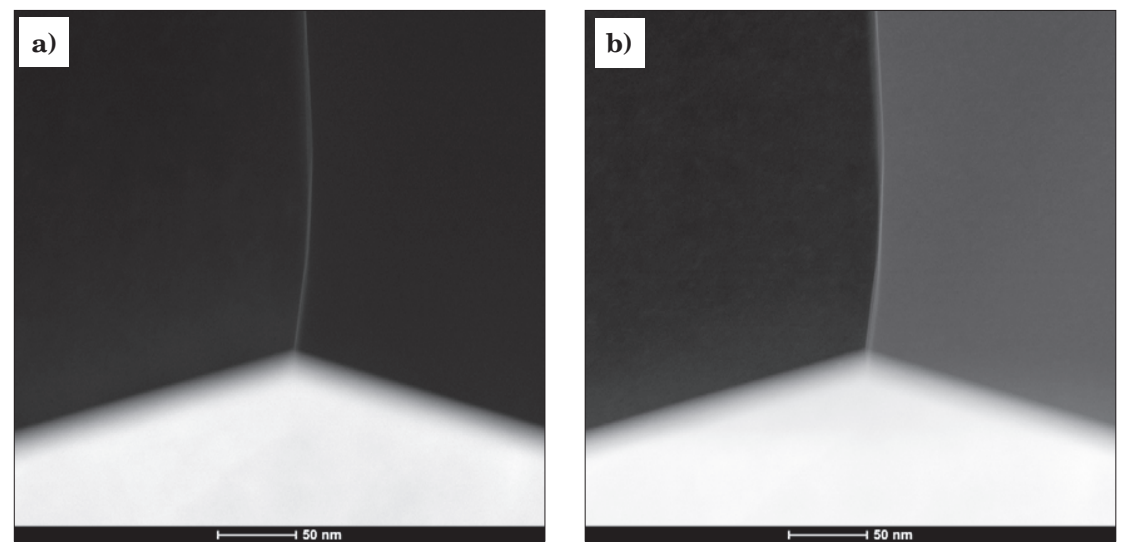

Fig. 12. STEM-HAADF (a) and DF (b) images of the $\alpha-\mathrm{Al}_{2} \mathrm{O}_{3}$ grains along with elemental distribution of: c) $\mathrm{Hf}$, d) $\mathrm{Al}$, e) $\mathrm{Ni}$ and f) $\mathrm{O}$

Rys. 12. Obrazy STEM-HAADF (a) i DF (b) granicy ziarn $\alpha-\mathrm{Al}_{2} \mathrm{O}_{3}$ oraz rozmieszczenie pierwiastków: c) $\mathrm{Hf}$, d) $\mathrm{Al}$, e) $\mathrm{Ni}$ i f) $\mathrm{O}$
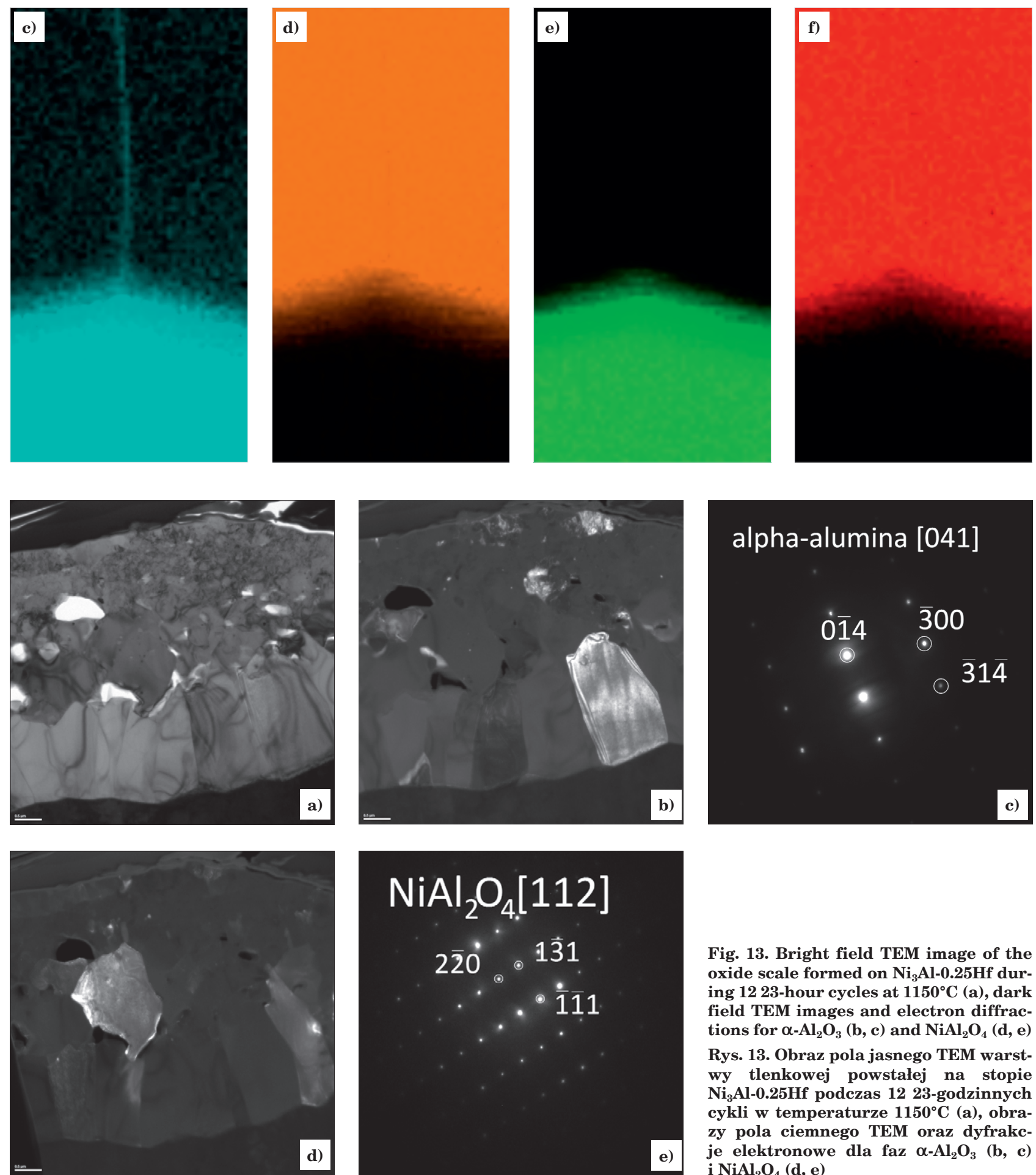

Fig. 13. Bright field TEM image of the oxide scale formed on $\mathrm{Ni}_{3} \mathrm{Al}-0.25 \mathrm{Hf}$ during 12 23-hour cycles at $1150^{\circ} \mathrm{C}$ (a), dark field TEM images and electron diffractions for $\alpha-\mathrm{Al}_{2} \mathrm{O}_{3}(\mathrm{~b}, \mathrm{c})$ and $\mathrm{NiAl}_{2} \mathrm{O}_{4}(\mathrm{~d}, \mathrm{e})$

Rys. 13. Obraz pola jasnego TEM warstwy tlenkowej powstałej na stopie $\mathrm{Ni}_{3} \mathrm{Al}-0.25 \mathrm{Hf}$ podezas 12 23-godzinnych cykli w temperaturze $1150^{\circ} \mathrm{C}$ (a), obrazy pola ciemnego TEM oraz dyfrakcje elektronowe dla faz $\alpha-\mathrm{Al}_{2} \mathrm{O}_{3}(\mathrm{~b}, \mathrm{c})$ i $\mathrm{NiAl}_{2} \mathrm{O}_{4}(\mathrm{~d}, \mathbf{e})$ 


\section{SUMMARY}

The paper presents the results of cyclic oxidation resistance tests at $1150^{\circ} \mathrm{C}$ of model $\mathrm{NiAl}$ and $\mathrm{Ni}_{3} \mathrm{Al}$ alloys and their modifications with various amounts of hafnium - from 0.25 to $1.5 \mathrm{wt} . \%$. Based on the mass change curves formed during the cyclic oxidation test, it was shown that increasing the Hf content in both alloys improves their cyclic oxidation resistance at $1150^{\circ} \mathrm{C}$. The highest resistance was exhibited by the $\mathrm{Ni}_{3} \mathrm{Al}-1.5 \mathrm{Hf}$ alloy as well as all Hf-containing $\mathrm{NiAl}$ alloys (above 46 23-hour cycles at $1150^{\circ} \mathrm{C}$ ).

It was shown that in the case of $\mathrm{Ni}_{3} \mathrm{Al}$ alloy, in the presence of $\mathrm{Hf}$, the growth of nickel oxides is limited and the adhesion of $\mathrm{Al}_{2} \mathrm{O}_{3}$ oxide scale is improved, which leads to an increased cyclic oxidation resistance. This effect was also observed in the case of NiAl alloys where no nickel oxides were formed, while the increase in oxidation resistance was related to improved alumina adhesion. Too high a content of $\mathrm{Hf}$ in the alloys leads to the formation of large Hf oxides within the oxide scale that could lead to its decohesion and compromise the adhesion to the substrate.

The detailed STEM investigation showed that the $\mathrm{Hf}$-free $\mathrm{Ni}_{3} \mathrm{Al}$ alloy as well as $\mathrm{Ni}_{3} \mathrm{Al}-0.25 \mathrm{Hf}$ forms an oxide scale with an outer $\mathrm{NiAl}_{2} \mathrm{O}_{4}$ and inner $\alpha-\mathrm{Al}_{2} \mathrm{O}_{3}$ zones. It was revealed that in the Hf-free alloy, sulphur is present in the form of nickel sulphides which are embedded in the inward grown $\alpha-\mathrm{Al}_{2} \mathrm{O}_{3}$ grains. In the presence of $\mathrm{Hf}$ in $\mathrm{Ni}_{3} \mathrm{Al}$, the formation of sulphides is inhibited. Moreover, it was found that hafnium oxides are formed within the outer $\mathrm{NiAl}_{2} \mathrm{O}_{4}$ layer of the oxide scale, while segregation of $\mathrm{Hf}$ occurs in grain boundaries of the internal $\alpha-\mathrm{Al}_{2} \mathrm{O}_{3}$ zone.

\section{REFERENCES}

[1] W.T. Griffiths, L.B. Pfeil. Improvements in Heat Resistant Alloys. UK Patent 459 (1937) 848. 1937.

[2] R. Swadźba, J. Wiedermann, M. Hetmańczyk, L. Swadźba, B. Mendala, B. Witala, Ł. Komendera. Microstructure degradation of EB-PVD TBCs on Pd-Pt-modified aluminide coatings under cyclic oxidation conditions. Surface and Coatings Technology, 2013, 237, p. 16-22.

[3] R. Swadźba L. Swadźba, J. Wiedermann, M. Hetmańczyk, B. Witala. Characterization of Alumina Scales Grown on a 2nd Generation Single Crystal Ni Superalloy During Isothermal Oxidation at 1050,1100 and $1150^{\circ} \mathrm{C}$. Oxidation of Metals, 2014, 82, p. 195-208.

[4] B.A. Pint. Progress in Understanding the Reactive Element Effect Since the Whittle and Stringer Literature Review. In John Stringer Symposium on High Temperature Corrosion. Materials Park, OH: ASM International, 2003, p. 9-19.

[5] H. Heuer, D.B. Hovis, J.L. Smialek, B. Gleeson. Alumina Scale Formation: A New Perspective. Journal of the American Ceramic Society A, 2011, 94, p. 146-153.

[6]B.A Pint. Experimental Observations in Support of the Dynamic-Segregation Theory to Explain the Reactive-Element Effect. Oxidation of Metals, 1996, 45, p. 1-37.

[7] D.P. Whittle, J. Stringer. Improvements in High Temperature Oxidation Resistance by Additions of Reactive Elements or Oxide Dispersions. Philosophical Transactions of The Royal Society, 1980, 295, 1413, p. 309-329.

[8] M. Homa. Żaroodporność i żarywotrzymałość stali typu Fe-Cr-Al. W warunkach utleniających: aktualny stan i perspektywy badań. Prace Instytutu Odlewnictwa, 2008, XLVIII, p. 57-86.

[9]A. Pint, I.G. Wright, W.Y. Lee, Y. Zhang, K. Prußner, K.B. Alexander. Substrate and bond coat compositions: factors af fecting alumina scale adhesion. Materials Science and Engineering, 1998, A245, p. 201-211.

[10] B.A. Pint, J.R. Martin, L.W. Hobbs, The oxidation mechanism of $\theta-\mathrm{Al}_{2} \mathrm{O}_{3}$ scales. Solid State Ionics, 1995, 78, p. 99-107.

[11] J.S. Sheasby, D.B. Jory. Electrical Properties of Growing Alumina Scales. Oxidation of Metals, 1978, 12, p. 527-539.
[12] D. Nicolas-Chaubet, A.M. Huntz, F. Millot. Electrochemical method for the investigation of transport properties of alumina scales formed by oxidation. Journal of Materials Science, 1991, 26, p. 6119-6126.

[13] K.A. Unocic, B.A. Pint. Effect of water vapor on thermally grown alumina scales on bond coatings. Surface \& Coatings Technology, 2013, 215, p. 30-38.

[14] K.A. Unocic, C.M. Parish, B.A. Pint. Characterization of the alumina scale formed on coated and uncoated doped superalloys. Surface \& Coatings Technology, 2011, 206, p. 1522-1528.

[15] A.H. Heuer, T. Nakagawa, M.Z. Aza, D.B. Hovis, J.L. Smialek, B. Gleeson, N.D.M. Hine, H. Guhl H.-S. Lee, P. Tangney, W.M.C. Foulkes, M.W. Finnis. On the growth of $\mathrm{Al}_{2} \mathrm{O}_{3}$ scales. Acta Materialia, 2013, 61, p. 6670-6683.

[16] W. Veal, A.P. Paulikas, B. Gleeson, P.Y. Hou. Creep in $\alpha-\mathrm{Al}_{2} \mathrm{O}_{3}$ Thermally Grown on $\beta-\mathrm{NiAl}$ and NiAlPt Alloys. Surface and Coatings Technology, 2007, 202, p. 608-612.

[17] J. Jedliński, J-L. Grosseau-Poussard, K. Kowalski, J. Dabek, G. Borchardt. Development of Oxide Scale at $1,100^{\circ} \mathrm{C}$ on Fe20Cr5Al Alloy Non-Implanted and Yttrium-Implanted. Oxidation of Metals, 2013, 79 (1-2), p. 41-51.

[18] J. Jedlinski G. Borchardt. On the Oxidation Mechanism of Alumina Formers. Oxidation of Metals, 1991, 36, p. 317-337.

[19] W.B. Michael. Reactive element modified chemical vapor deposition low activity. Surface and Coatings Technology, 2001, 146-147 (1), p. 7-12.

[20] B.A. Pint, K.L. More. Characterization of alumina interfaces in TBC systems. Journal of Materials Science, 2009, 44, p. $1676-1686$.

[21] R. Swadźba, J. Wiedermann, L. Swadźba, M. Hetmańczyk, B. Witala, U. Schulz, T. Jung. High temperature oxidation of EB-PVD TBCs on Pt-diffused single crystal $\mathrm{Ni}$ superalloy. Surface \& Coatings Technology, 2014, 260, p. 2-8.

[22] R. Swadźba. Interfacial phenomena and evolution of modified aluminide bondcoatings in Thermal Barrier Coatings. Applied Surface Science, 2018, 445, p. 133-144. 